\title{
Analisis Willingness To Pay Sistem Penyediaan Air Minum Menggunakan Contingent Valuation Method Di Kota Bandung (Studi Kasus Pelanggan I PA Dago Pakar)
}

\author{
YOLI NDA, KANCI TRA PHARMAWATI \\ J urusan Teknik Lingkungan, Fakultas Teknik Sipil dan Perencanaan, \\ Institut Teknologi Nasional (I tenas) Bandung \\ Email : chan.yolinda@gmail.com
}

\begin{abstract}
ABSTRAK
PDAM Tirtawening secara berkala mengkaji tarif air minum untuk mendukung perbaikan sistem penyediaan air minum di Kota Bandung. Kajian tarif air minum dari sisi pelanggan perlu dilihat untuk perbaikan pelayanan yang semakin meningkat sesuai harapan terutama dari sisi kuantitas, kontinuitas dan kualitasnya melalui kemauan membayar pelanggannya. Kemauan pelanggan membayar lebih dari yang biasa dibayarkan untuk barang lingkungan atau willingness to pay (WTP) dapat memberikan kontribusi untuk PDAM Tirtawening Kota Bandung. Besaran nilai WTP perlu diestimasi sehingga dapat memberikan gambaran tingkat kemauan membayar pelanggan dalam perbaikan pelayanan PDAM. Pelanggan PDAM dari IPA Dago Pakar menjadi objek penelitian ini dengan menggunakan Contigent Valuation Method (CVM). CVM merupakan suatu metoda teknik survei kepada responden tentang nilai yang mereka berikan terhadap komoditi yang tidak memiliki pasar seperti barang lingkungan untuk mengestimasi nilai barang lingkungan secara komprehensif. Berdasarkan hasil penelitian, nilai rata-rata WTP responden dari IPA Dago Pakar yang diperoleh adalah Rp. 130.857 per bulan dan nilai total WTP sebesar Rp 394.665.143. Nilai WTP tersebut dipengaruhi aspek pelayanan air minum yang dirasakan responden memuaskan. Pelaksanaan CVM dalam penelitian ini memiliki nilai $\mathrm{R}^{2}$ sebesar 0,816 atau $81,6 \%$ sehingga pelaksanaan metoda tersebut dapat diandalkan.
\end{abstract}

Kata kunci: sistem penyediaan air minum, tarif, IPA Dago Pakar, CVM, WTP

\begin{abstract}
PDAM Tirtawening periodically review drinking water's retribution to support the improvement of water supply system in Bandung. The review of drinking water retribution from customer needs to be seen for the enhancement of services which is increasing expected especially the quantity, continuity and quality from willingness to pay customers. The willingness to pay (WTP) customers contribute to PDAM Tirtawening Bandung. The value of the WTP should be estimated to give the level of willingness to pay customers's description in repair PDAM's service. PDAM customers from IPA Dago Pakar become the object in this research using Contigent Valuation Method (CVM). CVM is a survey techniques method to respondents about the commodities's value do not have a market like environmental goods to estimate it comprehensively. Based on the research, the WTP's average respondents from IPA Dago Pakar is Rp. 130,857 per month and the WTP's total is Rp $394,665,143$. WTP value is influenced from respondent's perceive about drinking water is satisfied. The CVM's $\mathrm{R}^{2}$ value is 0.816 or $81.6 \%$ so the implementation of the method is reliable.
\end{abstract}

Keywords: drinking water supply system, retribution, Dago Pakar Plant, CVM, WTP 


\section{PENDAHULUAN}

Peningkatkan jumlah konsumsi air bersih di suatu wilayah baik secara keseluruhan memperhatikan faktor yang mempengaruhi tingkat konsumsi air bersih pada perkotaan antara lain tarif air, jumlah penduduk, jumlah kepala keluarga, pendapatan regional dan perkembangan wilayah. Pada golongan rumah tangga yang mempengaruhi tingkat konsumsi diantaranya tarif air, jumlah penduduk dan jumlah kepala keluarga (Alimah, 2012).

Tarif air yang dikenakan pada pelanggan PDAM Tirtawening Kota Bandung penting dalam operasional PDAM. Pelanggan air minum PDAM Tirtawening dikenakan tarif air minum dengan struktur tarif yang beragam sesuai dengan standar peraturan yang berlaku. Tarif air yang dikenakan oleh pelanggan PDAM juga menjadi salah satu bentuk kontribusi penting terhadap pelayanan PDAM.

Pelayanan PDAM secara keseluruhan berada pada nilai kelas B (Baik) dimana pelayanan non teknis berpengaruh pada nilai tersebut. Pada pelayanan secara teknis (kualitas, kuantitas dan kontinuitas) berada pada kelas C (Kurang Baik) (Setiady,2013). Hal tersebut menunjukkan pelanggan PDAM kurang puas terhadap pelayanan eksisting sehingga pelanggan mengharapkan adanya jaminan pelayanan terutama pada kuantitas dan kontinuitas air minum yang digunakan. Peningkan pelayanan PDAM Tirtawening Kota Bandung selalu diupayakan dengan mengevaluasi aspek - aspek yang menunjang pelayanannya termasuk mengkaji tarif air minum.

Setiap lima tahun sekali PDAM selalu mengevaluasi tarif air minum. Evaluasi tersebut memerlukan analisa kajian tarif air minum yang dikaitkan kepada konsumen. Willingness to pay (WTP) menjadi salah satu kajian untuk mengetahui seberapa jauh kemamuan setiap pelanggan untuk membayar dalam rangka memperbaiki kondisi lingkungan sesuai dengan standar yang diharapkan. WTP dapat memberikan rekomendasi kajian tarif air minum untuk keberlangsungan perbaikan sistem penyediaan air minum sesuai dengan kondisi yang diharapkan pelanggan yaitu dari sisi kuantitas, kontinuitas dan kualitas. Objek penelitian ini adalah pelanggan PDAM dari IPA Dago Pakar yang memiliki kapasitas produksi air minum yang cukup besar.

Maksud dari penelitian ini adalah mengetahui tingkat kemauan membayar (willingness to pay) pelanggan terhadap sistem penyediaan air minum yang digunakan masyarakat Kota Bandung.

Tujuan dari penelitian ini adalah mengestimasi besaran nilai WTP terhadap sistem penyediaan air minum di Kota Bandung.

Metoda contigent valuation method (CVM) merupakan suatu metoda teknik survei dengan menanyakan kepada responden tentang nilai yang mereka berikan terhadap komoditi yang tidak memiliki pasar seperti barang lingkungan. Kelebihan CVM adalah satu - satunya metoda yang praktis dalam memperkirakan berbagai barang lingkungan. Metoda CVM memiliki kemampuan yang besar untuk mengestimasi manfaat lingkungan dari segi komprehensif dan kelengkapan serta kepraktisan yang tinggi dibandingkan dengan metoda valuasi lingkungan lainnya sehingga terpilih dalam penelitian ini (Merryna, 2009). 


\section{I. METODE PENELITI AN}

Tahapan penelitian yang digunakan dalam jurnal ini meliputi:

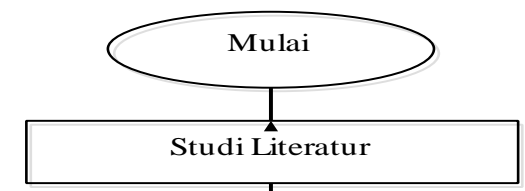

Survei Lapangan
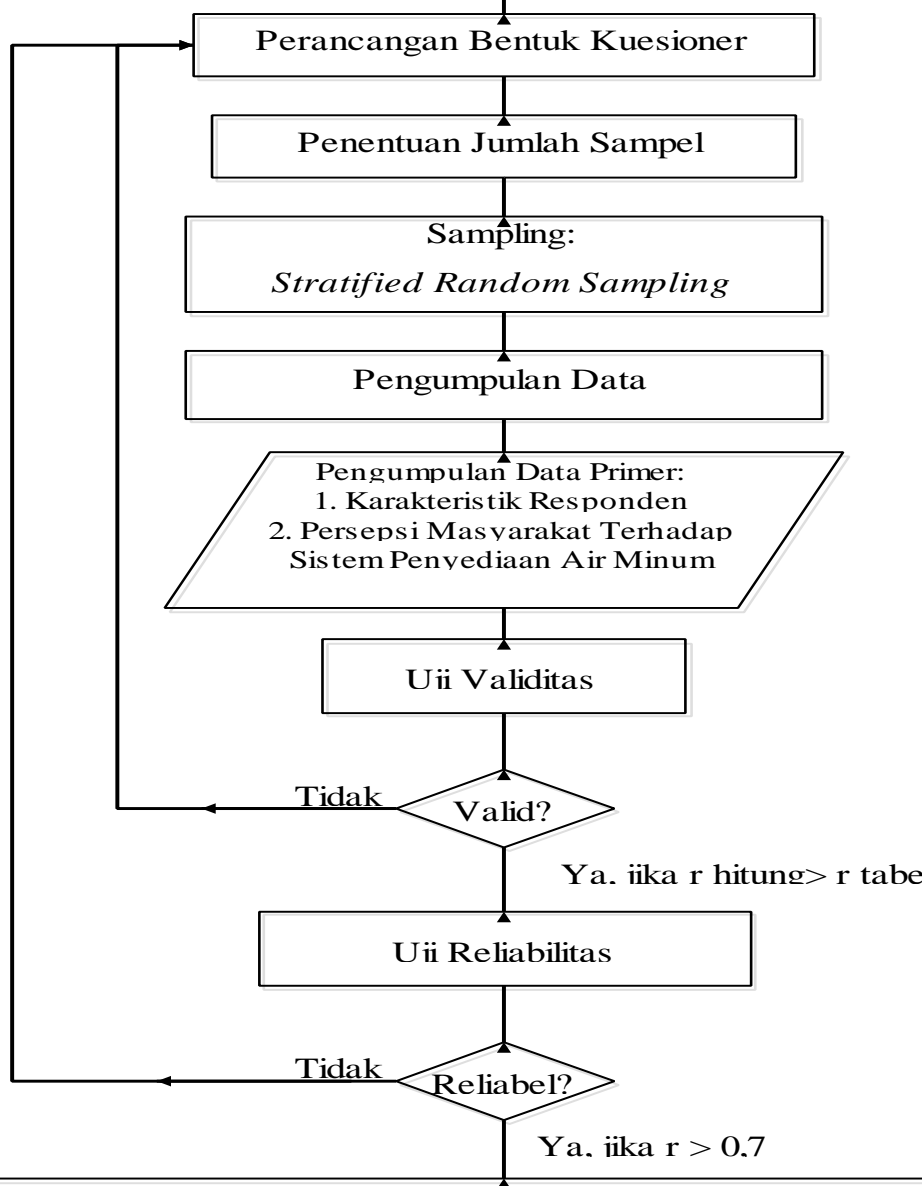

Pengolahan Data dan Analisa Data:

1. Analisis Validitas - Reliabilitas Instrumen

2. Analisis Nilai Willingness To Pay (WTP) dengan Metoda CVM

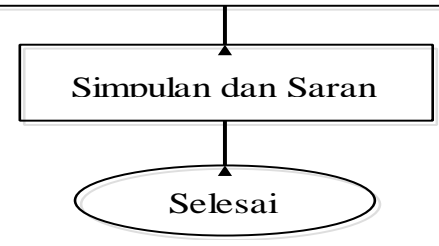




\subsection{Studi Literatur}

\section{Gambar 1. Diagram Penelitian}

Pada tahapan ini, studi literatur dilakukan dengan tujuan untuk memahami penelitian yang akan dilakukan dan mendapatkan literatur untuk mendukung penelitian. Studi literatur utama terkait penerapan contingent valuation method dalam kemauan pelanggan domestik untuk membayar air minum yang digunakan. Studi literatur untuk penelitian tersebut dapat bersumber dari buku, jurnal dan karya ilmiah.

\subsection{Pengumpulan Data Sekunder}

Tahapan Pengumpulan data sekunder menjadi tahapan selanjutnya setelh studi literatur. Pada tahapan ini, data sekunder diperoleh untuk mendukung tahapan selanjutnya dalam penelitian ini. Data Sekunder yang diperoleh berupa data jumlah pelanggan, dan dokumen lain dari PDAM Tirtawening dan profil Kota Bandung dari Badan Pusat Statistik (BPS).

\subsection{Persiapan Penelitian}

Pada tahap persiapan penelitian terdiri dari:

(a) Survei Lapangan

Survei lapangan berdasarkan berkaitan dengan lokasi penyebaran kuisioner terhadap pelanggan PDAM Kota Bandung dengan sumber air baku dari IPA Dago Pakar yang melayani pelanggan air minum di wilayah Utara.

(b) Perancangan bentuk kuisioner

Kuisioner yang akan digunakan pada penelitian ini menggunakan beberapa variabel yang terpilih. Variabel yang digunakan dalam kuisioner dapat dilihat dalam Tabel 1.

Tabel 1. Tabel Variabel Kuisioner

\begin{tabular}{|c|c|c|c|}
\hline No & Komponen & & Kategori \\
\hline 1 & Atribut Responden & & $\begin{array}{l}\text { Jenis kelamin, umur, pekerjaan, jumlah orang } \\
\text { tinggal dalam } 1 \text { Kepala Keluarga (KK), } \\
\text { pendidikan, penghasilan dan rata - rata tagihan } \\
\text { air per bulan. }\end{array}$ \\
\hline 2 & $\begin{array}{l}\text { Persepsi Responden } \\
\text { Pelayanan PDAM }\end{array}$ & & $\begin{array}{l}\text { Pelayanan air minum dari aspek kuantitas, } \\
\text { kontinuitas dan kualitas air. }\end{array}$ \\
\hline 3 & $\begin{array}{l}\text { Kemampuan } \\
\text { responden (Willingnes }\end{array}$ & $\begin{array}{l}\text { embayar } \\
\text { to Pay) }\end{array}$ & Bidding Games \\
\hline
\end{tabular}

(c) Penentuan jumlah sampel menggunakan rumus Slovin.

Untuk menentukan jumlah sampel yang akan diambil menggunakan rumus Slovin dengan persamaan sebagai berikut (Moleong, 2004):

$$
\mathrm{n}=\mathrm{N} 1+\mathrm{N}(\mathrm{e} 2)
$$

dimana:

$\mathrm{n}=$ jumlah sampel

$\mathrm{N}=$ jumlah penduduk total

e $=$ tingkat error (10\%)

Berdasarkan persamaan 1, dengan memperhitungkan populasi pelanggan PDAM sebesar 8669, diperoleh sampel sebanyak 35 responden dengan proporsi yang berbeda untuk setiap struktur tarif. Pada kelurahan Sukabungah terdapat 17 responden terdiri dari 6 responden golongan 2A2, 10 responden golongan $2 A 3$ dan 1 responden golongan 2A4. Kelurahan Pajajaran diambil 18 responden terdiri dari 8 responden golongan 2A2, 6 responden golongan $2 \mathrm{~A} 3$ dan 4 responden golongan $2 \mathrm{~A} 4$. 


\subsection{Sampling}

Pada penelitian ini menggunakan teknik Stratified Random Sampling atau teknik pengambilan sampel acak distratifikasi dimana teknik sampling yang digunakan bila suatu populasi makin heterogen sehingga makin besar perbedaan sifat antara lapisan tersebut. Sampling pada penelitian ini didasarkan pada tarif air minum berdasarkan Peraturan Walikota No. 270 Tahun 2013 yang dijelaskan pada Tabel 2.

Tabel 2. Tabel Tarif Air Minum

\begin{tabular}{llcccc}
\hline No & $\begin{array}{c}\text { Pemakaian } \\
\text { ( } \mathbf{m}^{3} \mathbf{)}\end{array}$ & $\mathbf{2 A 1}$ & $\mathbf{2}$ Struktur Tarif (Rp) & $\mathbf{2 A 3}$ & $\mathbf{2 A 4}$ \\
\hline 1 & $1-10$ & 1.000 & 2.000 & 2.600 & 3.300 \\
2 & $11-20$ & 1.600 & 3.600 & 4.600 & 6.000 \\
3 & $21-30$ & 2.300 & 5.700 & 7.400 & 9.400 \\
4 & $>30$ & 5.500 & 8.800 & 10.700 & 12.600 \\
\hline
\end{tabular}

Sumber: Peraturan Walikota No. 270 Tahun 2013

Keterangan:

$2 \mathrm{~A} 1=$ Rumah tangga golongan rumah susun perumnas

2A2 = Rumah tangga golongan yang terletak di jalan kecil / gang dengan lebar jalan kurang dari 2 meter

$2 \mathrm{~A} 3=$ Rumah tangga golongan rumah yang terletak di jalan besar bukan protokol dengan lebar jalan tidak kurang dari 2 meter dan tidak lebih dari 4 meter.

2A4 = Rumah tangga golongan rumah dengan lebar jalan diatas 4 meter bukan jalan protokol, rumah peristirahatan, villa, bungalow yang tidak dikomersilkan, perumahan real estate / rumah dengan luas bangunan diatas $300 \mathrm{~m}^{2}$, atau luas tanah diatas $500 \mathrm{~m}^{2}$, apartemen / kondominium.

\subsection{Pengumpulan Data Primer dan Pemeriksaan Keabsahan Data}

Pengumpulan data primer dilakukan melalui wawancara dan pembagian kuisioner kepada responden pada lokasi penelitian terpilih. Sedangkan pada pengumpulan data sekunder diperoleh dokumen terkait profil Kota Bandung, jumlah pelanggan dan dokumen lain dari PDAM Tirtawening.

Pemerikasaan keabsahan data diperlukan untuk mengukur alat instrumen yang digunakan sahih (validitas) dan andal (reliabilitas) sesuai dengan tuntutan pengetahuan, kriteria dan paradigma penelitian terkait (Moleong, 2004). Penelitian ini menggunakan instrumen yaitu kuesioner sehingga validitas dan reliabilitas harus diuji terlebih dahulu.

Uji validitas pada penelitian ini dihitung dengan menggunakan SPPS yang hasil pengukuran dikorelasikan dengan teknik korelasi "product moment". Angka korelasi yang diperoleh dibandingkan dengan angka kritik pada tabel angka kritik. Untuk taraf signifikansi 5\% angka kritik adalah 0,632. Bila angka korelasi yang diperoleh ( $r$ hitung) lebih besar dari angka kritik pada tabel ( $r$ tabel) maka kuesioner tersebut memiliki validitas yang sahih.

Uji reliabilitas pada penelitian ini dihitung dengan menggunakan SPPS dengan rumus Spearman Brown. Nilai koefisien reliabilitas atau Alpha (Cronbach) dinyatakan cukup baik mulai dari nilai diatas 0,7 . Pengukuran reliabilitas mutlak dilakukan untuk mengetahui kuesioner yang digunakan dapat diandalkan atau tidak (Janti, 2014).

\subsection{Analisis}

Analisis yang dilakukan dalam penelitian ini mencakup:

1. Analisis validitas - reliabilitas instrumen penelitian, dan 
2. Analisis nilai willingness to pay (WTP) responden terhadap pembayaran jasa lingkungan berdasarkan metoda Contingent Valuation Method (CVM).

\subsection{Simpulan}

Simpulan dari penelitian ini adalah kemampuan masyarakat dalam membayar (willingness to pay) sistem penyediaan air minum yang digunakan yang dinyatakan dalam nilai Rupiah ( $R p)$.

\section{ISI}

\subsection{Gambaran Umum Wilayah Studi}

Kota Bandung terletak di wilayah Jawa Barat merupakan Ibukota Propinsi Jawa Barat. Secara astronomis, Kota Bandung terletak di antara $107^{\circ}$ 36' Bujur Timur dan $6^{\circ}$ 55' Lintang Selatan dengan ketinggian 700 Meter di atas permukaan laut (dpl). Titik tertinggi di Kelurahan Ledeng Kecamatan Cidadap dengan ketinggian 892 meter dpl dan terendah di kelurahan Rancanumpang Kecamatan Gedebage dengan ketinggian 666 meter dpl.

Sistem perpipaan distribusi PDAM Tirtawening Kota Bandung memiliki keterbatasan suplai jaringan pipa, sehingga pipa dengan diameter besar saling terhubung satu sama lain untuk memberikan tambahan suplai ke wilayah jaringan yang memiliki debit dan tekanan yang sangat rendah. Untuk melayani seluruh pelanggan, distribusi air dilakukan dengan sistem gilir di sebagian besar wilayah distribusi. Sistem Pendistribusian PDAM Tirtawening Kota Bandung dibagi menjadi 4 (empat) wilayah dengan wilayah Utara sebagai lokasi penelitian.

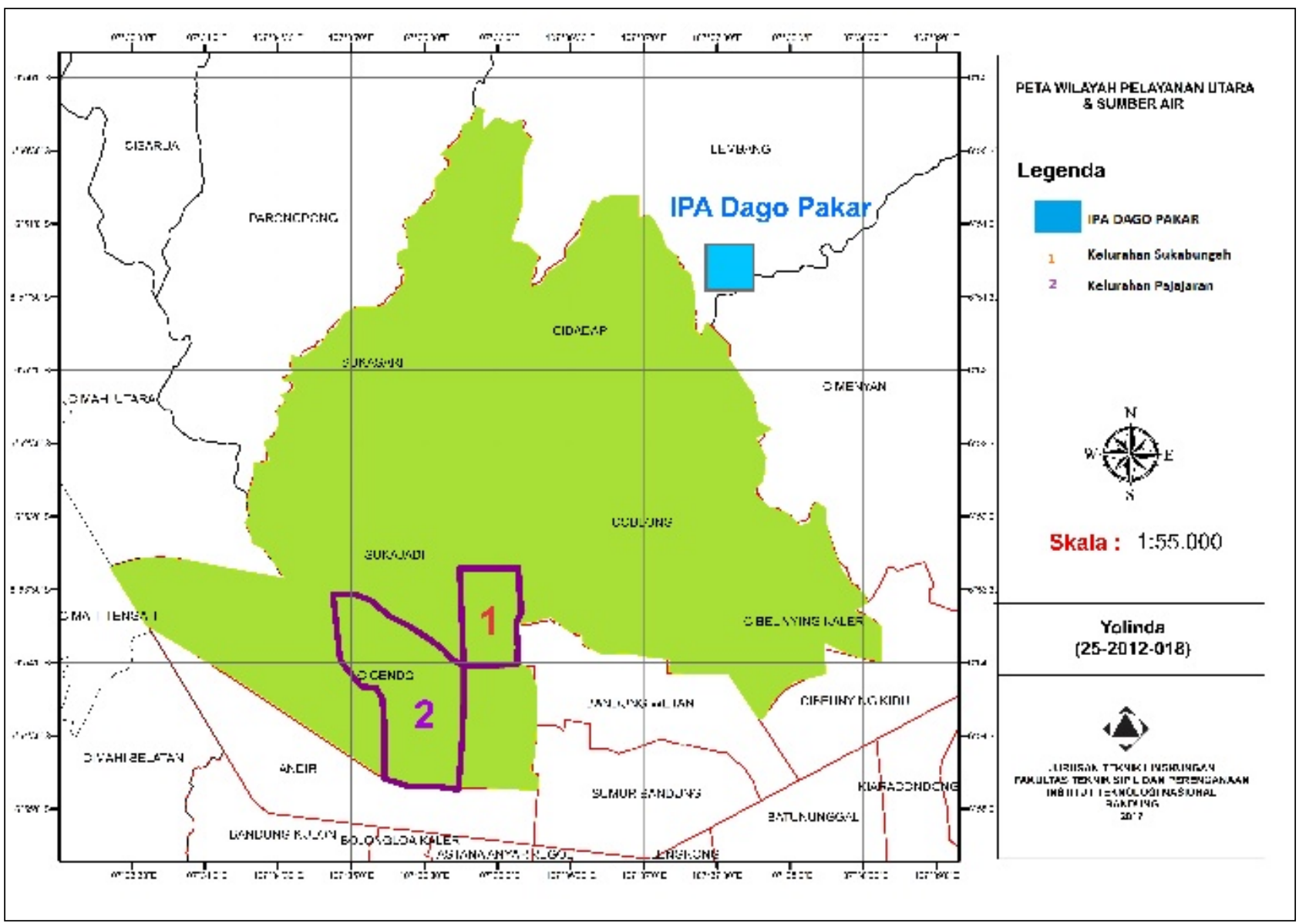

Gambar 2. Peta Lokasi Titik Sampling 
Pemilihan wilayah lokasi penelitian didasarkan pada data dari PDAM seperti data wilayah dengan sumber air baku, data wilayah pelayanan PDAM Tirtawening di Kota Bandung memperhitungkan jarak antar lokasi penelitian dan didukung oleh data tingkat kepuasan pelanggan PDAM Tirtawening dengan kategori puas dari Setiady (2013). Berdasarkan data data dan justifikasi tersebut, diambil 2 kelurahan di Kota Bandung mewakili wilayah pelayanan utara dengan tingkat kepuasan yang puas dan di layani oleh sumber air baku hanya dari IPA Dago Pakar. Berikut 2 kelurahan yang terpilih berada pada Tabel 3.

Tabel 3. Tabel Lokasi Penelitian Terpilih

\begin{tabular}{llcc}
\hline No & Kelurahan Terpilih & Wilayah Pelayanan & Sumber Air \\
\hline 1 & Kelurahan Sukabungah & Utara & IPA Dago Pakar \\
2 & Kelurahan Pajajaran & & \\
\hline
\end{tabular}

\subsection{Analisis Validitas - Reliabilitas I nstrumen Penelitian}

Pada bagian ini, kuesioner sebagai instrumen dalam penelitian ini diuji coba terlebih dahulu. Setelah jumlah responden sudah di dapat, lalu kuesioner disebarkan. Hasil dari kuesioner lalu diuji validitas dan reliabilitasnya untuk melihat seberapa valid (nyata) dan dapat diandalkan atau tidak kuesioner yang digunakan dalam penelitian ini.

Hipotesa awal terkait kuesioner dalam penelitian ini adalah kemauan membayar pelanggan domestik terhadap pelayanan sistem penyediaan air minum PDAM Kota Bandung diduga dipengaruhi oleh faktor - faktor seperti penilaian terhadap aspek kuantitas dan kontinuitas serta kualitas pelayanan PDAM terhadap WTP.

Tabel 4. Hasil Uji Validitas Kuisioner

\begin{tabular}{|c|c|c|c|c|c|}
\hline No & Komponen & Kategori & Hipotesa & $\begin{array}{l}\text { Nilai Validitas } \\
\text { ( } r \text { hitung) }\end{array}$ & Nilai $r$ tabel 0,632 \\
\hline \multirow[t]{7}{*}{$A$} & Atribut & Umur & & 0,852 & $r$ hitung $>r$ tabel : VALID \\
\hline & Responden & Jenis Kelamin & & 0,691 & $r$ hitung $>r$ tabel : VALID \\
\hline & & Pekerjaan & & 0,834 & $r$ hitung $>r$ tabel : VALID \\
\hline & & Pendidikan & & 0,758 & $r$ hitung $>r$ tabel : VALID \\
\hline & & $\begin{array}{l}\text { Jumlah orang dalam satu } \\
\text { KK }\end{array}$ & - & 0,771 & $r$ hitung $>r$ tabel : VALID \\
\hline & & Penghasilan & & 0,746 & $r$ hitung $>r$ tabel : VALID \\
\hline & & $\begin{array}{l}\text { Rata - rata Tagihan PDAM } \\
\text { perbulan }\end{array}$ & & 0,692 & $r$ hitung $>r$ tabel : VALID \\
\hline \multirow[t]{4}{*}{ B } & Penilaian & Volume air bersih dari & Responden dengan & & \\
\hline & $\begin{array}{l}\text { Kuantitas } \\
\text { Air }\end{array}$ & $\begin{array}{l}\text { PDAM sudah dapat } \\
\text { memenuhi, kurang atau } \\
\text { tidak }\end{array}$ & $\begin{array}{l}\text { pelayanan kuantitas } \\
\text { air yang baik } \\
\text { memberikan nilai }\end{array}$ & 0,857 & $r$ hitung $>r$ tabel : VALID \\
\hline & & $\begin{array}{l}\text { Penggunaan sumber air } \\
\text { bersih selain PDAM }\end{array}$ & $\begin{array}{l}\text { WTP yang lebih } \\
\text { kecil daripada } \\
\text { responden dengan }\end{array}$ & 0,725 & $r$ hitung $>r$ tabel : VALID \\
\hline & & $\begin{array}{l}\text { Penggunaan pompa untuk } \\
\text { mengalirkan air PDAM }\end{array}$ & $\begin{array}{l}\text { pelayanan kuantitas } \\
\text { air yang kurang } \\
\text { baik }\end{array}$ & 0,639 & $r$ hitung $>r$ tabel : VALID \\
\hline $\mathrm{C}$ & $\begin{array}{l}\text { Penilaian } \\
\text { Kontinuitas } \\
\text { Air }\end{array}$ & $\begin{array}{l}\text { Jadwal pengaliran air oleh } \\
\text { PDAM dalam seminggu }\end{array}$ & $\begin{array}{l}\text { Responden dengan } \\
\text { pelayanan } \\
\text { kontinuitas air yang } \\
\text { baik memberikan }\end{array}$ & 0,662 & $r$ hitung $>r$ tabel : VALID \\
\hline
\end{tabular}




\begin{tabular}{|c|c|c|c|c|c|}
\hline \multirow[b]{2}{*}{ No } & \multirow[b]{2}{*}{ Komponen } & \multirow[b]{2}{*}{ Kategori } & $\begin{array}{lll}\text { nilai } & \text { WTP } & \text { yang } \\
\text { lebih } & & \\
\end{array}$ & \multirow[b]{2}{*}{$\begin{array}{l}\text { Nilai Validitas } \\
\text { ( } r \text { hitung) }\end{array}$} & \multirow[b]{2}{*}{ Nilai $r$ tabel 0,632} \\
\hline & & & Hipotesa & & \\
\hline \multirow{6}{*}{$\mathrm{D}$} & \multirow{6}{*}{$\begin{array}{l}\text { Penilaian } \\
\text { Kualitas Air }\end{array}$} & $\begin{array}{l}\text { Durasi air PDAM mengalir } \\
\text { per hari }\end{array}$ & $\begin{array}{l}\text { kecil daripada } \\
\text { responden dengan } \\
\text { pelayanan } \\
\text { kontinuitas air yang } \\
\text { kurang baik. }\end{array}$ & 0,881 & $r$ hitung $>r$ tabel : VALID \\
\hline & & $\begin{array}{l}\text { Pernah / tidak / sering } \\
\text { kehabisan air PDAM }\end{array}$ & & 0,722 & $r$ hitung $>r$ tabel : VALID \\
\hline & & $\begin{array}{l}\text { Kejernihan air yang baru } \\
\text { keluar dair keran }\end{array}$ & $\begin{array}{l}\text { Responden dengan } \\
\text { pelayanan kualitas }\end{array}$ & 0,686 & $r$ hitung $>r$ tabel : VALID \\
\hline & & mengendap di dasar bak & $\begin{array}{l}\text { memberikan nilai } \\
\text { WTP yang lebih }\end{array}$ & 0,690 & $r$ hitung $>r$ tabel $:$ VALID \\
\hline & & Bau Kaporit & $\begin{array}{l}\text { kecil daripada } \\
\text { responden dengan }\end{array}$ & 0,714 & $r$ hitung $>r$ tabel $:$ VALID \\
\hline & & Rasa pahit/ asam / sepat & $\begin{array}{l}\text { pelayanan } \\
\text { air yanglitas } \\
\text { baik }\end{array}$ & 0,714 & $r$ hitung $>r$ tabel : VALID \\
\hline$E$ & WTP & $\begin{array}{lr}\text { Kesediaan } & \text { membayar } \\
\text { dengan } & \text { peningkatan } \\
\text { pelayanan } & \end{array}$ & $\begin{array}{l}\text { WTP menjadi } \\
\text { variabel utama } \\
\text { (variabel terikat) }\end{array}$ & 1 & $r$ hitung $>r$ tabel : VALID \\
\hline
\end{tabular}

Sumber: Hasil Olah Data, 2017

Berdasarkan hasil uji validitas pada Tabel 4 menunjukkan nilai $r$ hitung dari setiap komponen pertanyaan memiliki angka yang lebih tinggi dari pada nilai $r$ tabel dimana nilai yang digunakan sebesar 0,632 . Nilai $r$ tabel yang digunakan berdasarkan taraf signifikansi sebesar $5 \%$ sehingga item pertanyaan dari tiap komponen dinyatakan bersifat valid.

Tabel 5. Tabel Hasil Uji Reliabilitas

\begin{tabular}{cccc}
\hline \multirow{2}{*}{ No } & \multirow{2}{*}{ Komponen } & \multicolumn{2}{c}{ Reliability Statistics } \\
& Cronbach's Alpha & N of I tems \\
\hline 1 & A & 0,783 & 8 \\
2 & B & 0,786 & 4 \\
3 & C & 0,800 & 4 \\
4 & D & 0,778 & 5 \\
5 & E & 1,000 & 2 \\
\hline
\end{tabular}

Sumber: Hasil Olah Data, 2017

Pada Tabel 5 menunjukkan setiap bagian komponen pertanyaan yaitu komponen A, B, C, D, dan E memiliki nilai Cronbach's Alpha lebih besar dari 0,7 dan semua komponen dalam kuesioner dinyatakan cukup baik sehingga bersifat reliabel. Kuesioner yang dinyatakan valid dan reliabel menunjukkan bahwa penelitian menggunakan kuesioner dengan pertanyaan 
yang ada sudah konsisten dan tepat sasaran sehingga dapat dijadikan acuan untuk menjadi instrumen penelitian ini.

\subsection{Analisis Nilai Willingness To Pay (WTP)}

a. Memperkirakan Nilai Rata - Rata WTP (EWTP)

Nilai WTP yang diajukan kepada responden memiliki nilai beragam mulai dari Rp 50.000 per bulan hingga Rp 230.000 per bulan untuk peningkatan pelayanan PDAM Tirtawening Kota Bandung. Setelah mendapat nilai WTP melalui metoda bidding games, maka nilai WTP yang diperoleh diurutkan menjadi kelas WTP dengan melihat frekuensi dari jumlah responden yang mengajukan nilai WTP tersebut. Nilai WTP yang sudah diklasifikasikan lalu dihitung nilai dugaan WTP atau Estimating Mean WTP (EWTP) dengan persamaan berikut (Merryna, 2009).

$$
E W T P=\sum_{i=1} W_{i} P_{f i}
$$

Dimana:

$$
\begin{array}{ll}
\text { EWTP } & =\text { Dugaan rataan WTP } \\
\text { Wi } & =\text { Nilai WTP ke-i } \\
\text { Pfi } & =\text { Frekuensi Relatif } \\
\mathrm{n} & =\text { Jumlah responden } \\
\mathrm{I} & =\text { Responden ke-i yang bersedia membayar WTP }
\end{array}
$$

Tabel 6. Distribusi Nilai WTP Responden di Kota Bandung (Pelanggan I PA Dago Pakar)

\begin{tabular}{ccccc}
\hline No & Kelas WTP (Rp) & $\begin{array}{c}\text { Frekuensi } \\
\text { (Responden) }\end{array}$ & $\begin{array}{c}\text { Frekuensi } \\
\text { Relatif (Pfi) }\end{array}$ & EWTP (Rp) \\
\hline 1 & 50.000 & 1 & 0,029 & 1.429 \\
2 & 60.000 & 1 & 0,029 & 1.714 \\
3 & 70.000 & 2 & 0,057 & 4.000 \\
4 & 80.000 & 1 & 0,029 & 2.286 \\
5 & 100.000 & 6 & 0,171 & 17.143 \\
6 & 110.000 & 4 & 0,114 & 12.571 \\
7 & 120.000 & 5 & 0,143 & 17.143 \\
8 & 130.000 & 0 & 0 & 0 \\
9 & 140.000 & 0 & 0 & 0 \\
10 & 150.000 & 5 & 0,143 & 21.429 \\
11 & 160.000 & 3 & 0,086 & 13.714 \\
12 & 170.000 & 1 & 0,029 & 4.857 \\
13 & 180.000 & 1 & 0,029 & 5.143 \\
14 & 200.000 & 4 & 0,114 & 22.857 \\
15 & 230.000 & 1 & 0,029 & 6.571 \\
& TOTAL & 35 & 1 & $\mathbf{1 3 0 . 8 5 7}$ \\
\hline
\end{tabular}

Sumber: Hasil Perhitungan, 2017

Berdasarkan Tabel 6, nilai EWTP di IPA Dago Pakar sebesar Rp 130.857 per bulan. Pengaruh dari nilai EWTP IPA Dago Pakar salah satunya akibat dari aspek pelayanan air minum yang dirasakan responden sudah cukup baik dibuktikan dengan hasil kuesioner sehingga pelanggan membayar WTP sebesar nilai tersebut.

b. Memperkirakan Kurva WTP 
Setelah nilai dugaan WTP (EWTP) diperoleh, kurva penawaran WTP dibuat dengan melihat nilai WTP yang diajukan oleh responden dengan jumlah tertentu. Gambar 3 dibawah ini menjelaskan kurva WTP pada responden di IPA Dago Pakar

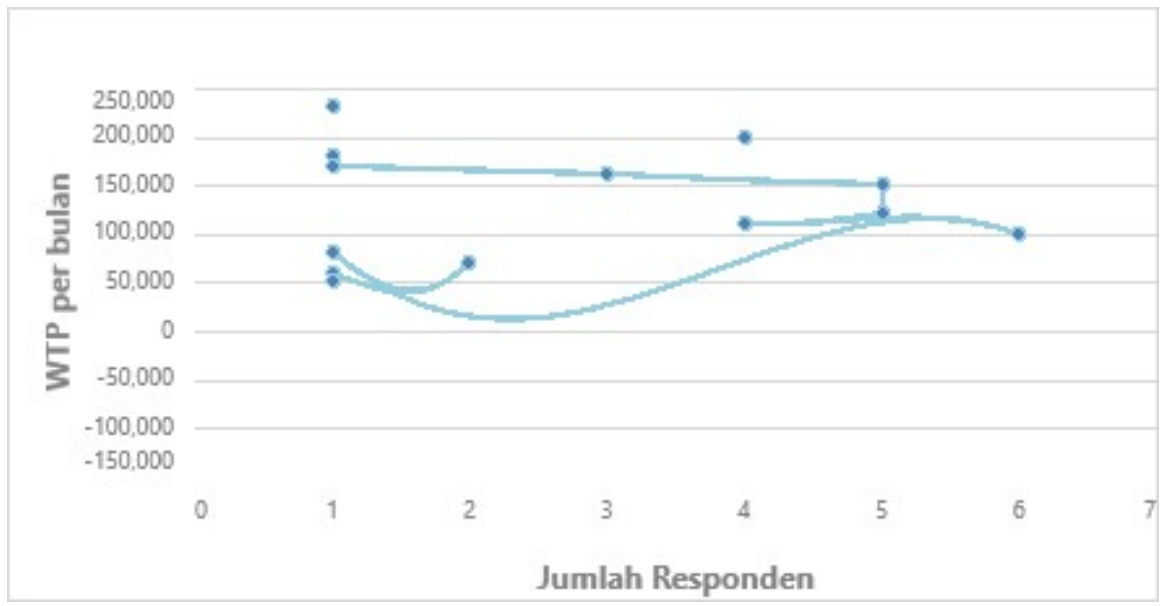

Gambar 3. Kurva Penawaran WTP I PA Dago Pakar (Sumber: Hasil Olah Data, 2017)

Berdasarkan kurva WTP pada Gambar 3, pelanggan sumber IPA Dago Pakar mayoritas membayar WTP sebesar Rp 100.000 per bulan. Hal tersebut disebabkan pelanggan cukup puas dengan pelayanan PDAM eksisting sehingga untuk peningkatan pelayanan PDAM dari kondisi eksisting, pelanggan hanya mau membayar dengan rata - rata Rp 100.00 per bulan.

c. Menjumlahkan Data Total WTP (TWTP)

Setelah mendapat nilai WTP melalui metoda bidding games, maka nilai WTP yang diperoleh diurutkan menjadi kelas dengan nilai WTP tertentu mulai dari nilai WTP terendah hingga nilai WTP yang terbesar dengan menghitung frekuensi dari jumlah responden yang mengajukan nilai WTP tersebut. Nilai WTP yang sudah diklasifikasikan lalu dihitung nilai total WTP (TWTP) dengan persamaan berikut (Merryna, 2009).

$$
\text { TWTP= } \mathrm{i}=1 \text { WTPi ni(N)P }
$$

Dimana:

TWTP $\quad=$ Total WTP

WTPi = WTP individu sampel ke-i

ni $\quad=$ Jumlah sampel ke-i yang bersedia membayar sebesar WTP

$\mathrm{N} \quad=$ Jumlah sampel

P $\quad=$ Jumlah populasi

i $\quad=$ Responden ke-i yang bersedia membayar pembayaran jasa lingkungan

Tabel 7. Distribusi Nilai TWTP Responden di Kota Bandung (Pelanggan I PA Dago Pakar)

\begin{tabular}{cccccc}
\hline No & $\begin{array}{c}\text { Kelas WTP } \\
\text { (Rp) }\end{array}$ & $\begin{array}{c}\text { Frekuensi } \\
\text { Responden } \\
\text { (ni) }\end{array}$ & $\begin{array}{c}\text { Frekuensi } \\
\text { Relatif } \\
\text { (ni/ N) }\end{array}$ & $\begin{array}{c}\text { Populasi } \\
\text { Pelanggan } \\
\text { PDAM (P) }\end{array}$ & TWTP (Rp) \\
\hline 1 & 50.000 & 1 & 0,029 & 86 & 4.308 .571 \\
2 & 60.000 & 1 & 0,029 & 86 & 5.170 .286 \\
3 & 70.000 & 2 & 0,057 & 172 & 12.064 .000 \\
4 & 80.000 & 1 & 0,029 & 86 & 6.893 .714 \\
5 & 100.000 & 6 & 0,171 & 517 & 51.702 .857
\end{tabular}




\begin{tabular}{cccccc}
6 & 110.000 & 4 & 0,114 & 345 & 37.915 .429 \\
7 & 120.000 & 5 & 0,143 & 431 & 51.702 .857 \\
8 & 130.000 & 0 & 0 & 0 & 0 \\
9 & 140.000 & 0 & 0 & 0 & 0 \\
\hline No & $\begin{array}{c}\text { Kelas WTP } \\
\text { (Rp) }\end{array}$ & $\begin{array}{c}\text { Frekuensi } \\
\text { Responden } \\
\text { (ni) }\end{array}$ & $\begin{array}{c}\text { Frekuensi } \\
\text { Relatif } \\
\text { (ni/ N) }\end{array}$ & $\begin{array}{c}\text { Populasi } \\
\text { Pelanggan } \\
\text { PDAM (P) }\end{array}$ & TWTP (Rp) \\
\hline 10 & 150.000 & 5 & 0,143 & 431 & 64.628 .571 \\
11 & 160.000 & 3 & 0,086 & 259 & 41.362 .286 \\
12 & 170.000 & 1 & 0,029 & 86 & 14.649 .143 \\
13 & 180.000 & 1 & 0,029 & 86 & 15.510 .857 \\
14 & 200.000 & 4 & 0,114 & 345 & 68.937 .143 \\
15 & 230.000 & 1 & 0,029 & 86 & 19.819 .429 \\
& TOTAL & 35 & 1 & 3.016 & $\mathbf{3 9 4 . 6 6 5 . 1 4 3}$ \\
\hline
\end{tabular}

Sumber: Hasil Perhitungan, 2017

Berdasarkan Tabel 7, nilai TWTP sebesar Rp 394.665.143. Nilai TWTP tersebut mewakili WTP untuk seluruh pelanggan PDAM di IPA Dago Pakar dan aspek pelayanan air minum yang pelanggan rasakan puas.

\section{d. Analisis Penggunaan CVM}

Pada tahap ini memerlukan pendekatan seberapa besar tingkat keberhasilan dalam pengaplikasian CVM melalui uji yang dapat dilakukan dengan melihat nilai $\mathrm{R}^{2}$ dari analisa regresi linear berganda WTP. Nilai $\mathrm{R}^{2}$ tersebut menunjukkan hubungan antara variabel terikat dan variabel bebas. Berdasarkan Tabel 4, variabel terikat adalah nilai WTP yang diajukan responden dan variabel bebas yaitu variabel pada aspek kuantitas, kontinuitas dan kualitas. Berdasarkan hasil analisa regresi linear berganda yang diuji pada responden yang berasal dari IPA Dago Pakar didapatkan nilai $R^{2}$ sebesar 0,816 atau $81,6 \%$. Besaran nilai $R^{2}$ pada lokasi responden IPA Dago Pakar sebesar $81,6 \%$ menunjukkan hubungan antara variabel terikat dengan variabel bebas yang sangat kuat. Hal tersebut berdasarkan kriteria hubungan variabel dimana pada rentang 0,80 1,00 menyatakan korelasi yang sangat kuat (Sugiyono, 2016). Hasil tersebut menunjukkan pelaksanaan metoda CVM pada penelitian ini sudah cukup baik dan dapat diyakini kebenaran dan keandalannya.

\section{KESI MPULAN}

Berdasarkan hasil penelitian ini, nilai rataan WTP responden dari IPA Dago Pakar adalah Rp. 130.857 per bulan dengan nilai total WTP adalah Rp. Rp 394.665.143 per bulan. Dari nilai WTP tersebut menunjukkan responden di IPA Dago Pakar hanya mau membayar dengan nilai tersebut disebabkan kondisi eksisting sistem penyediaan air minum di wilayahnya cukup baik.

Penggunaan CVM dalam menerapkan besaran WTP dari pelanggan IPA Dago Pakar cukup baik bila dilihat dari besaran nilai $\mathrm{R}^{2}$ sebesar 0,816 atau $81,6 \%$. Nilai tersebut menunjukkan hubungan sangat kuat sehingga pelaksanaan metoda CVM ini dapat diandalkan.

\section{UCAPAN TERI MA KASI H}

Terimakasih kepada Instittut Teknologi Nasional (Itenas) melalui Program Kreativitas Mahasiswa Itenas (PROKIMNAS) yang telah membiayai penelitian ini.

\section{DAFTAR PUSTAKA}


Alimah, Iklima. 2012. Jurnal PWK dan SAPPK V3N2 : Kajian Tingkat Konsumsi Air Bersih PDAM di Provinsi J awa Barat. Bandung; Institut Teknologi Bandung

Janti, Suhar. 2014. Analisis Validitas Dan Reliabilitas Dengan Skala Likert Terhadap Pengembangan Si/Ti Dalam Penentuan Pengambilan Keputusan Penerapan Strategic Planning Pada Industri Garmen. Prosiding Seminar Nasional Aplikasi Sains \& Teknologi (SNAST).

Merryna, Annisa. 2009. Analisis Willingness To Pay Masyarakat Terhadap Pembayaran Jasa Lingkungan Mata Air Cirahab (Desa Curug Goong, Kecamatan Padarincang, Kabupaten Serang, Banten). Bogor; Institut Pertanian Bogor.

Moleong, Lexy J. 2004. Metodologi Penelitian Kualitatif: Edisi Revisi. Bandung: PT. Remaja Rosdakarya

PDAM Kota Bandung. 2014. Rencana Pengamanan Air Minum PDAM Kota BANDUNG. Bandung: PDAM Kota Bandung

Peraturan Walikota Bandung No. 270 Tahun 2013 Tentang Pengaturan Tarif Pelayanan Air Minum dan Air Limbah Pada Perusahaan Daerah Air Minum Tirtawening Kota Bandung

Setiady, Yayan Nuryaman. 2013. Analisis Kepuasan Pelanggan Di PDAM Tirtawening Kota Bandung Dengan Metode SERVQUAL. Bandung: Institut Teknologi Bandung

Sugiyono, 2016. Metode Penelitian Pendidikan. Bandung. Alfabeta 